\title{
Impact of Trade Openness on Economic Growth among ECOWAS Countries: 1975-2017
}

\begin{abstract}
Victor U. Ijirshar ${ }^{1}$
This study assesses the impact of trade openness on economic growth among ECOWAS countries using secondary data from 1975 to 2017. The study uses non-stationary heterogeneous dynamic panel models through the application of Pooled Mean Group (PMG) and Mean Group (MG) estimators since time dimension was more than cross-sections. Using the Hausman test, PMG estimator was preferred. Results show that trade openness has positive effects on growth in ECOWAS countries in the long-run but mixed effects in the short-run. The study therefore recommends that ECOWAS member countries improve cooperation among economic actors by using export consortia so as to help SMEs in the region access international markets and to pursue a twin strategy of trade and competitiveness.
\end{abstract}

Keywords: exchange rate, exports, imports, international trade, trade openness and economic growth.

JEL Classification: F1, F14, F43

DOI: $10.33429 /$ Cjas.10119.4/6

\subsection{Introduction}

Trade openness is the liberalization of the exchange of goods and services across borders through increased integration among countries. These countries are joined together in terms of free movement of capital and labour, and free foreign trade and finance (Igudia, 2004). However, the debate surrounding the relationship between trade openness and economic growth in developing economies is between pro-traders and anti-traders (Oluwatoyin \& Folasade, 2014).

Pro-traders: those in favour of foreign trade, date back to Smith's (1776) analysis of market specialisation and Ricardo's (1932) theory of comparative advantagethat openness promotes efficient allocation of resources and allows for the dis-

\footnotetext{
${ }^{1}$ Department of Economics, Benue State University, Makurdi, Nigeria. Email: ijirsharvictor@gmail.com, Tel: +234(0)8134705084
} 
semination of knowledge and technology and improved levels of competition in international and domestic markets. Moreover, some scholars revealed long-run growth effect of trade openness (Chang, Kaltani \& Loayza, 2009; Young, 1991; Grossman \& Helpman, 1991b; Lee, 1993; Eicher, 1999).

On the contrary, if market or institutional imperfections exist, foreign trade can lead to under-utilization of capital and human resources, and over concentration in extractive activities- with insignificant returns (Matsuyama, 1992; Grossman \& Helpman, 1991). Thus, examining the impact of foreign trade openness on growth among ECOWAS member countries is an important empirical exercise.

Given the growth trend among ECOWAS countries, several attempts and programs have been established in the quest to accelerate economic growth in West African countries. Among them are; the United States Agency for International Development (USAID) and West Africa Trade Program (WATP), West African Economic and Monetary Union (WAEMU) and Economic Community of West African States (ECOWAS) with the aim of improving product quality by farmers. ECOWAS was originally established with the aim of promoting trade among member countries and the imposition of uniform trade barriers such as ECOWAS Common External Tariff (CET) to international markets. The question is, does foreign trade openness significantly affect growth in ECOWAS member countries? This question has not been given any significant empirical attention since the inception of ECOWAS. The objective of this study therefore is to provide a framework that will fill the existing empirical gap and to assess the exact impact of foreign trade openness on growth of ECOWAS member countries.

The rest of the paper is structured as follows: Section 2 focuses on theoretical framework and empirical literature. Section 3 covers methodology while section 4 deals with analysis and results. Section 5 concludes the paper. 


\subsection{Literature Review}

\subsection{Theoretical Framework}

The study employed Solow-Swan neo-classical growth model that was introduced by Solow (1956) and Swan (1956). The essence of the Solow-Swan neoclassical growth theory is that the potential rate of growth of output which represents the equilibrium and 'natural' rates of growth -is determined exogenously by the rate of growth of the labor force and technological progress. The focus of the theory is on the reconciliation of the actual and natural rates of growth. It is a simple structure of a well-behaved production function, investment-saving relation, and a labor growth function. In Solow's model, the growth process follows a balanced growth path. According to Solow (1956), Output per worker along the balanced growth path is determined by technology, investment rate and the population growth rate and that growth in output and in the volume of international trade are closely related. However, Solow had emphasized the importance of technological change in the long-term economic growth rate but what determines technological progress was left unanswered and assumed to be exogenous (Barro \& Sala-i-Martin, 2004).

The theory states that growth of an economy is best judged in terms of its closeness to theoretical optimum. The criticism associated with the theory is regarding its fundamental assumptions that diminishing returns to capital, perfect competition and technological change are exogenous. But, Mankiw, Romer and Weil (1992) created a human capital augmented version of the Solow-Swan model that explains the failure of international investment to flow to poor countries (Mankiw, Romer \& Weil, 1992). In this model output and the marginal product of capital $(\mathrm{K})$ are lower in poor countries because they have less human capital than rich countries using the production function of Cobb-Douglas.

The Solow-Swan growth theory explains the determinants of economic growth and explicitly states that income per person along the balanced growth path is determined by technology, investment rate and the population growth rate and that there is a relationship between output growth and volume of international trade. Additionally, since West African countries are developing economies and are char- 
acterized as being backward technologically, they are expected to enjoy "sudden great spurts" of industrial and economic growth as backwardness leads to rapid advancement according to the Catch-up theory of Veblen (1915), Gerschenkron (1962) and Abramovitz (1986).

On the other hand, the absolute advantage theory, the comparative advantage theory and the Heckscher-Ohlin theory provide the basis for mutually beneficial trade between countries as they engage in international trade.

The contribution of trade to growth varies depending on whether the force of comparative advantage directs the economy's resources towards activities that generate long-run growth or away from such activities. Moreover, theories suggest that, due to technological or financial constraints, less-developed countries may lack the social capability required to adopt technologies developed in more advanced economies. Thus, the growth effect of trade may differ according to the level of economic development. Despite its potential positive effect on growth, some theoretical studies claim that international trade may hamper growth (Young, 1991; Lucas, 1988). For Redding (1999), Young (1991), and Lucas (1988), opening up to trade might actually reduce long-run growth if an economy specializes in sectors with dynamic comparative disadvantage in terms of potential growth or where technological innovations or learning by doing are largely exhausted. For such economies, selective protection may foster faster technological advances and economic growth.

\subsection{Empirical Literature}

Zahonogo (2017) investigated how trade affects economic growth in developing countries using sub-Saharan Africa (SSA) countries. The study employed a dynamic growth model with data from 42 SSA countries covering 1980 to 2012 . The Pooled Mean Group estimation technique was considered and result indicates that a trade threshold exists below which greater trade openness has beneficial effects on economic growth and above which the trade effect on growth declines. The evidence also indicated an inverted U-curve (Laffer Curve of Trade) to changes in trade openness measures and to alternative model specifications suggesting a 
non-fragility linkage between economic growth and trade openness for sub-Saharan African countries. These findings support the view that the relation between trade openness and economic growth is not linear for SSA. However, since the author did not take cognizance of larger cross sections (42) relative to time dimension (33). Since the time dimension (33 years) was relatively less than cross sections (42 SSA countries), it violates the assumptions for the application of panel Auto-regressive Lag Models such as Pooled Mean Group estimation technique.

Iyoha and Okim (2017), analyzed the impact of trade on economic growth on ECOWAS member countries using panel data from 1990 to 2013. Using four estimators; pooled OLS, Fixed effects model, Random effects model, and dynamic panel regression model although dynamic panel data estimator was preferred to handle the problem of endogeneity, they found that exports, exchange rate and investment were significant determinants of per capita real income growth and that exports were consistently positively related to growth, suggesting that trade has a significant positive impact on economic growth in ECOWAS member countries. This study however fell short in terms of the scope covered for the analysis and the conditions for choosing between Pooled Mean Group estimator and Mean Group estimator through the application of Hausman test. The test would have determined whether the differences in estimated coefficients are systematic or not.

Kim, Lin and Suen (2016) examined the relationship between trade, economic growth and growth volatility using the Chudik and Pesaran (2013) Cross-Sectional Augmented Autoregressive Distributed Lag (CS-ARDL) panel data approach covering the period 1960 to 2011. The study used a sample of 73 developing and developed countries to account for the potential dynamic heterogeneity and crosssection dependency in the effects of trade. The results showed that greater international trade promotes economic growth and amplifies growth volatility in the long run. The study also found that there is large heterogeneity in the effects of trade, depending upon a country's development level, financial system, macroeconomic policies, human capital, corruption, and labor regulation. However, it could not capture most of the ECOWAS member countries where it is assumed that the effect may differ due to market and institutional imperfections. 
In an attempt to close the gap on the free-trade-growth link, Manwa and Wijeweera (2016) conducted a study on five Southern African countries; Botswana, Lesotho, Namibia, South Africa, and Swaziland covering 1980 to 2011. The AutoRegressive Distributed Lag (ARDL) was used to obtain short-run and longrun impacts of trade liberalization policies on economic growth. The study used the average tariff rate as a proxy for trade liberalization in model 1 and trade ratios in Model 2. The results from the two models suggest that Southern Africa has clearly benefited from its trade liberalization policies both in short-run and longrun. However, the study is limited in scope as it fails to cover ECOWAS member states.

\subsection{Methodology}

\subsection{Data and Variables}

The study used panel data from 1975 to 2017. This study relied essentially on secondary data from World Bank and the International Monetary Fund (IMF). Brief explanation of variables follows as:

Economic growth: the annual increase or improvement in the real per capita income (real GDP per capita or output per person) in an economy. In this study, annual real GDP is the monetary value of all final goods and services at market prices in US dollars with year 2010 as the base year. This data is sourced from World Bank.

Trade openness: trade between two or more countries. It is measured in this study as total trade expressed as percent of GDP. This data is sourced from World Bank.

Government Spending: government final consumption expenditure formerly known as general government consumption. It includes all government current expenditures for purchases of goods and services including compensation of employees and most expenditure on national defense and security. It excludes government 
military expenditures that are part of government capital formation. This data is sourced from World Bank in current U.S. dollars.

Gross Fixed Capital Formation ( GFCF): Gross capital formation formerly gross domestic investment consists of outlays on additions to the fixed assets of the economy plus net changes in the level of inventories. This data is sourced from World Bank in current U.S. dollars.

Foreign Direct Investment: direct investment equity flows in an economy. It is the sum of reinvestment of earnings, equity capital and other capital. This data is sourced from World Bank in current U.S. dollars.

Exchange Rate (local currency units per U.S. dollar): It refers to the exchange rate determined by national authorities or to the rate determined in the legally sanctioned exchange market. This data is sourced from International Monetary Fund (IMF).

Labor Force: It comprises people ages 15 and older who supply labor to produce goods and services during a specified period. This data is sourced from World Bank.

\subsection{Model Specification}

The study used Dynamic Panel Data. Pooled Mean Group (PMG) and Mean Group (MG) estimators (Dynamic Panel Data estimators) were employed since time dimension ( 43 years) was more than cross-sections (15 countries). The estimated model was developed using the augmented version of the Solow-Swan model modeled by Mankiw, Romer and Weil (1992) that incorporated human capital.

$$
Y_{i t}=A_{i t} f\left(K_{i t}^{\alpha} H_{i t}^{\beta} L_{i t}^{1-\alpha-\beta}\right)
$$

where

$Y_{i t}=$ Real Output

$K_{i t}=$ Capital Accumulation or composition

$L_{i t}=$ Labour of Population Growth 
$H_{i t}=$ Stock of human capital.

$t$ is time $i$ cross sections, $0<\alpha<1$ elasticity of output (with respect to capital), elasticity of output (with respect to labour), $Y_{i t}$ annual output and $A_{i t}$ labour knowledge or augmenting technology. Transforming the model by taking natural logarithm, equation 1 becomes:

$$
\ln Y_{i t}=\alpha \ln K_{i t}+\beta \ln K_{i t}+(1-\alpha-\beta) \ln L_{i t}+\eta_{i}+\nu_{i t}
$$

where $i=1, \ldots, N$ and $t=1, \ldots, T, \eta_{i}+\nu_{i t}$ is the error components (decomposition of the error term); $\mathrm{N}$ is number of countries, $\mathrm{T}$ is fixed while $/ \alpha /<1$.

This study is built essentially from determinants of economic growth captured by the augmented version of the Solow-Swan model. Hence, following the augmented version of Solow-Swan (1956) model, the econometric model becomes:

$$
\begin{aligned}
\ln R G D P P_{i t}=\beta_{0}+ & \beta_{1} \ln I T O P_{i t}+\beta_{2} \ln L A B F_{i t}+\beta_{3} \ln G F C F_{i t}+\beta_{4} \ln F D I_{i t} \\
& +\beta_{5} \ln G E X_{i t}+\beta_{6} \ln E X R_{i t}+\eta_{i}+\nu_{i t}
\end{aligned}
$$

where :

RGDPP $=$ GDP per capita

ITOP $=$ Trade Openness

$\mathrm{LABF}=$ Labour Force

GFCF $=$ Gross Fixed Capital Formation

FDI $=$ Foreign Direct Investment

GEX $=$ Government Expenditure

$\mathrm{EXR}=$ Official Exchange Rate

ln = Natural Logarithm (the model was transformed to reduce skewness, produce nearly equal spreads and a nearly linear and/or additive relationship).

Following dynamic linear panel model in autoregressive form;

$$
\begin{gathered}
y_{i t}=\alpha y_{i, t-1}+\beta^{\prime} x_{i t}+U_{i t} \\
U_{i t}=\eta_{i}+\nu_{i t}
\end{gathered}
$$


The dynamic linear panel application allows the inclusion of $x_{i t-1}$ which provides an autoregressive panel model:

$$
y_{i t}=\alpha y_{i, t-1}+\beta_{1}^{\prime} x_{i t}+\beta_{2}^{\prime} x_{i t-1}+\eta_{i}+\nu_{i t}
$$

Applying the above typical linear dynamic panel model to equation 6 in assessing the impact of foreign trade openness on economic growth, the model is re-stated as:

$\ln R G D P P_{i t}=\beta_{0}+\delta \ln R G D P P_{i, t-1}+\beta_{1} \ln I T O P_{i t}+\beta_{2} \ln L A B F_{i t}+\beta_{3} \ln G F C F_{i t}$

$$
+\beta_{4} \ln F D I_{i t}+\beta_{5} \ln G E X_{i t}+\beta_{6} \ln E X R_{i t}+\eta_{i}+\nu_{i t}
$$

where:

$\beta_{0}=$ Intercept

$\beta_{1}-\beta_{6}=$ Parameter Coefficients to be estimated

$\eta_{i}=$ Individual Specific Effect or Fixed Effect

$\nu_{i t}=$ An idiosyncratic error

Equation 8 is re-specified to capture the error correction term $\left(e c_{i, t-1}\right)$

$$
\begin{gathered}
\ln R G D P P_{i t}=e c_{i, t-1}++\sum_{j=1}^{p} \delta_{i} \ln R G D P P_{i, t-j}+\sum_{j=0}^{q} \beta_{1 i} \ln I T O P_{i, t-j} \\
+\sum_{j=0}^{q} \beta_{2 i} \ln L A B F_{i, t-j}+\sum_{j=0}^{p} \beta_{3 i} \ln G F C F_{i t-j}+\sum_{j=o}^{q} \beta_{4 i} \ln F D I_{i, t-j} \\
+\sum_{j=0}^{q} \beta_{5 i} \ln G E X_{i, t-j}+\sum_{j=o}^{q} \alpha_{5 i} \ln G E X_{i, t-j}+\sum_{j=o}^{q} \alpha_{6 i} \ln E X R_{i, t-j} \\
+\alpha_{1 i} \ln I T O P_{i t}+\alpha_{2 i} \ln L A B F_{i t}+\alpha_{3 i} \ln G
\end{gathered}
$$

The error correction version of the equation 8 yields the following:

$$
\begin{aligned}
& \ln \Delta R G D P P_{i t}=e c_{i, t-1}+\sum_{j=1}^{p} \delta_{i} \ln \Delta R G D P P_{i, t-j}+\sum_{j=0}^{q} \beta_{1 i} \ln \Delta I T O P_{i, t-j} \\
& +\sum_{j=0}^{q} \beta_{2 i} \ln \Delta L A B F_{i, t-j}+\sum_{j=0}^{q} \beta_{3 i} \ln \Delta G F C F_{i, t-j}+\sum_{j=0}^{q} \beta_{4 i} \ln \Delta F D I_{i, t-j}
\end{aligned}
$$




$$
+\sum_{j=0}^{q} \alpha_{5 i} \ln \Delta G E X_{i, t-j}+\sum_{j=0}^{q} \alpha_{6 i} \ln \Delta E X R_{i, t-j}+\eta_{i}+\nu_{i t}
$$

but

$$
\begin{gathered}
e c_{i, t-1}=\theta_{i}\left[R G D P P_{i, t-j}-\alpha_{1 i} \ln I T O P_{i t}-\alpha_{2 i} \ln L A B F_{i t}-\alpha_{3 i} \ln G F C F_{i t}\right. \\
\left.-\alpha_{4 i} \ln F D I_{i t}-\alpha_{5 i} \ln G E X_{i t}-\alpha_{6 i} \ln E X R_{i t}\right]
\end{gathered}
$$

$\theta_{i}=-\left(1-\delta_{i}\right)$, group specific speed of adjustment coefficient (expected that $\theta_{i} \prec 0$ ) $e c_{i, t-1}$ measures how long it takes the system to converge to its long-run equilibrium.

\subsection{Analysis and Results}

\subsection{Analysis and Results}

The results of descriptive statistics (mean and standard deviation) are presented

\begin{tabular}{|c|c|c|c|c|c|c|c|c|c|c|c|c|c|c|}
\hline \multirow[t]{2}{*}{ Country } & \multicolumn{2}{|c|}{ RGDPP (US\$) } & \multicolumn{2}{|c|}{ ITOP (\%) } & \multicolumn{2}{|c|}{$\begin{array}{c}\text { LABF } \\
\text { (Million People) }\end{array}$} & \multicolumn{2}{|c|}{$\begin{array}{c}\text { GFCF } \\
\text { (US\$ Billion) }\end{array}$} & \multicolumn{2}{|c|}{$\begin{array}{c}\text { FDI } \\
\text { (US\$ Billion) }\end{array}$} & \multicolumn{2}{|c|}{$\begin{array}{c}\text { GEX } \\
\text { (US\$ Billion) }\end{array}$} & \multicolumn{2}{|c|}{$\begin{array}{c}\text { EXR } \\
\text { (A:USS) }\end{array}$} \\
\hline & Mean & SD & Mean & SD & Mean & SD & Mean & SD & Mean & $\mathrm{SD}$ & Mean & $\mathrm{SD}$ & Mean & SD \\
\hline Benin & 675.12000 & 87.56000 & 54.38000 & 7.26000 & 3.12000 & 0.78000 & 0.79800 & 0.78500 & 0.05400 & 0.09900 & 0.52100 & 0.46800 & 438.86000 & 149.83000 \\
\hline Burkina-Faso & 435.75000 & 120.28000 & 39.47000 & 7.290 & & 0.92000 & 1.07000 & 1.04 & 0.07000 & & 0.96000 & 0.87000 & & \\
\hline Cape Verde & 2023.69000 & 1092.59000 & 92.35000 & 12.210 & & 0.05000 & 0.70000 & 0.12000 & 0.06000 & 0.06000 & 0.31000 & 0.02 & & \\
\hline Gambia & 499.00000 & 18.40000 & 76.94000 & 24.55000 & 0.45000 & 1.22000 & 0.79000 & 0.62000 & 0.22000 & 0.02500 & 0.07000 & 0.02000 & 16.00000 & 13.59000 \\
\hline Ghana & 1030.24000 & 290.72000 & 58.26000 & 29.19000 & 8.94000 & 1.73000 & 3.81000 & 4.88000 & 0.81000 & 1.29000 & 1.57000 & 1.81000 & 0.74000 & 1.12000 \\
\hline Guinea & 2.96000 & 88.88000 & 65.45000 & 20.95000 & 3.48000 & 0.69000 & 1.29000 & 1.44000 & 0.17000 & 0.35000 & 0.55000 & 0.49500 & 2398.79000 & 2789.82000 \\
\hline Guinea-Bissau & 579.61000 & 55.68000 & 49.56000 & 8.72000 & 0.56000 & 0.12000 & 0.06000 & 0.03000 & 0.00700 & 0.01000 & 0.05200 & 0.03 & 438.87000 & 149.83000 \\
\hline Ivory Coast & 1546.99000 & 363.28000 & 75.52000 & & 6.34000 & & 2.25000 & 1.86000 & 0.21000 & 0.19000 & & & 438.87000 & 149.83000 \\
\hline Liberia & 9.78000 & 65.28000 & & & 1.020 & & 0.38000 & 0.19600 & 2000 & 0.60 & 3000 & 0.20 & 92000 & 15.89000 \\
\hline Mali & & 113.1 & & & $4.740 \mathrm{c}$ & & 1.13000 & 1.003 & & 0.16 & 0000 & 0.79 & 36000 & 149.83000 \\
\hline & & & 49.28000 & 9.89000 & 5.4300 & 1.55000 & 0.82000 & 0.95000 & 0.16000 & 0.29000 & 0.48000 & 0.36 & 438.86 & 149.8 \\
\hline & & & 33.94000 & 12.58000 & $42.3200 \mathrm{C}$ & 8.9100 & 46.73000 & 30.82000 & 2.87000 & 2.57000 & 10.45000 & 13.80 & 22000 & 79.75000 \\
\hline & & 113.90000 & 63.02000 & 8.92000 & 3.0900 & 0.63000 & 1.95000 & 1.53000 & 0.13000 & 0.16000 & & 0.79000 & 438.86500 & 149.83000 \\
\hline & 409.49000 & 74.02000 & 51.38000 & 16.89000 & 1.9200 & 0.36000 & 0.26000 & 0.31000 & 0.09700 & 0.21000 & 0.15000 & 0.12000 & 1744.19000 & 1969.89600 \\
\hline Togo & 560.43000 & 59.92000 & 89.65000 & 18.42000 & 2.52000 & 0.58000 & 0.39000 & 0.29000 & 0.06000 & 0.12000 & 0.25000 & 0.16000 & 438.86000 & 149.83000 \\
\hline
\end{tabular}
in Table 1.

Table 1: Descriptive Statistics

Cape Verde recorded the highest average annual real GDP per capita of US $\$ 2023.69$ followed by Nigeria with an average annual GDP per capita of US\$1783.49. Niger recorded the least annual real GDP per capita with an average of US $\$ 385.72$ during the study period. In terms of trade openness, Liberia has the highest average percentage of trade openness with $134.82 \%$ followed by Cape Verde and Togo with $92.35 \%$ and $89.65 \%$ respectively while Nigeria has the least average percentage of 
trade openness of $33.94 \%$. Nigeria also has the highest average labour force, gross fixed capital formation, foreign direct investment and government expenditure of 42.32 million people, US $\$ 46.73$ billion, US $\$ 2.87$ billion and US $\$ 10.45$ billion respectively. However, Cape Verde has the least average labour force of 0.18 million people while Togo has the least average gross fixed capital formation of US $\$ 0.06$ billion during the study period. Guinea-Bissau has least average foreign direct investment and government expenditure with US $\$ 0.007$ billion and US $\$ 0.052$ billion respectively. In terms of exchange rate, Guinea has the highest exchange rate of 2398.79 GNF: $1 \mathrm{US} \$$ while Ghana has the least exchange rate of $0.74 \mathrm{GH} \not \subset: 1 \mathrm{US} \$$.

\subsection{Panel unit root tests results}

The results of panel unit root tests are presented in Table 2.

Table 2: Panel Stationarity Test Results

\begin{tabular}{|c|c|c|c|c|c|c|c|c|}
\hline \multirow[b]{2}{*}{ Variables } & \multicolumn{2}{|c|}{ Levin, Lin and Chu (LLC) } & \multicolumn{2}{|c|}{ Hadri LM } & \multicolumn{2}{|c|}{ Im, Pesaran and Shin (IPS) } & \multirow[b]{2}{*}{$\begin{array}{l}\text { Order of } \\
\text { Integration }\end{array}$} & \multirow[b]{2}{*}{ Remark } \\
\hline & $\begin{array}{c}\text { Adjusted } \\
\text { t-statistics }\end{array}$ & $\mathrm{p}$-Value & Z-Statistics & $\mathrm{p}$-Value & $\begin{array}{c}\text { W-t-bar } \\
\text { Statistics }\end{array}$ & $\mathrm{p}$-Value & & \\
\hline Loge RGDPP & 0.85900 & 0.80480 & 72.22430 & 0.00000 & 2.11830 & 0.98290 & & Not Stationary \\
\hline D. loge RGDPP & -8.76230 & 0.00000 & 6.20560 & 0.00000 & -11.82220 & 0.00000 & 1(1) & Stationary \\
\hline Loge ITOP & -0.89700 & 0.18480 & 39.96270 & 0.00000 & -1.77150 & 0.03820 & & Not Stationary \\
\hline D. loge ITOP & -11.82720 & 0.00000 & -1.83900 & 0.96700 & -14.24310 & 0.00000 & 1(1) & Stationary \\
\hline Loge LABF & 3.21070 & 0.99930 & 70.24640 & 0.00000 & 2.13500 & 0.98360 & & Not Stationary \\
\hline D. loge LABF & -4.27080 & 0.00000 & 23.86710 & 0.00000 & -3.68290 & 0.00010 & 1(1) & Stationary \\
\hline Loge GFCF & 0.00790 & 0.50320 & 40.41510 & 0.00000 & 1.95620 & 0.97480 & & Not Stationary \\
\hline D. loge GFCF & -12.09060 & 0.00000 & -3.43340 & 0.99970 & -15.64740 & 0.00000 & 1(1) & Stationary \\
\hline Loge FDI & -2.02970 & 0.02120 & 17.07560 & 0.00000 & -1.22730 & 0.10980 & & Not Stationary \\
\hline D. loge FDI & -9.98220 & 0.00000 & -3.97750 & 1.00000 & -13.93030 & 0.00000 & $1(1)$ & Stationary \\
\hline Loge GEX & -0.68570 & 0.24650 & 73.03960 & 0.00000 & 2.18800 & 0.98570 & & Not Stationary \\
\hline D. loge GEX & -12.17700 & 0.00000 & 2.18480 & 0.01450 & -13.47890 & 0.00000 & 1(1) & Stationary \\
\hline Loge EXR & -0.09580 & 0.46180 & 82.68320 & 0.00000 & 2.13190 & 0.98350 & & Not Stationary \\
\hline D. loge EXR & -2.60030 & 0.00470 & 14.10070 & 0.00000 & -4.69030 & 0.00000 & 1(1) & Stationary \\
\hline
\end{tabular}

Table 2 shows the panel stationarity test results. The results indicate that all the panels contain unit roots at levels except for Foreign Direct Investment (FDI) in Levin, Lin and Chu (LLC) test and Trade Openness (ITOP) in Im, Pesaran and Shin (IPS) test. Based on the majority of the results with special attention to Im, Pesaran and Shin panel unit root test results, we conclude that some variables were stationary at first difference at $5 \%$ level of significance. Deducing from the above therefore, the specified growth equation is estimated at first difference of the variables to yield robust results. 


\subsection{Impact of trade openness on economic growth among ECOWAS member states}

The result of Hausman test is presented in Table 3. The result contains the estimates of MG and PMG estimators to know whether or not the difference in the estimated coefficients between the two techniques employed are systematic. The rule of thumb is that if the probability value chi-square of the Hausman test is less than $5 \%$ level of observed significance, the null hypothesis is rejected (Ho: differences in estimated coefficients are not systematic) and we conclude that the differences in coefficients are systematic. In this case, the MG estimator is preferred- otherwise the PMG estimator is used instead. Sigmamore is used in the specification and estimation of the Hausman test.

Table 3: Hausman Test Results for Model One

\begin{tabular}{|c|c|c|c|c|}
\hline & (b) & (B) & (b-B) & $\begin{array}{l}\text { Square Root of } \\
\text { the Diagonal } \\
(\mathrm{V} \text { b-V_B }) \text { ) }\end{array}$ \\
\hline & MG & PMG & Differences & S.E \\
\hline LogeITOP & -0.09829 & 0.20905 & -0.30734 & 0.13315 \\
\hline LogeLABF & 0.31200 & 0.64322 & -0.33122 & 0.15437 \\
\hline LogeGFCF & -0.09312 & -0.00534 & -0.08779 & 0.18027 \\
\hline LogeFDI & 0.00373 & 0.02845 & -0.02473 & 0.20525 \\
\hline LogeGEX & 0.00924 & 0.10798 & -0.09874 & 0.14403 \\
\hline LogeEXR & -0.02555 & 0.01965 & -0.04520 & 0.09119 \\
\hline \multicolumn{5}{|c|}{$\mathrm{b}=$ consistent under Ho and Ha; obtained from xtpmg; } \\
\hline \multirow{2}{*}{\multicolumn{5}{|c|}{$\begin{array}{l}B=\text { inconsistent under } \mathrm{Ha} \text {, efficient under } \mathrm{Ho} \text {; obtained from xtpmg; } \\
\text { Test: Ho: difference in coefficients not systematic; } \\
\text { chi2 }(6)=(b-B)^{\prime}\left[\left(V_{-} b-V \_B\right)^{\wedge}(-1)\right](b-B)=3.84 \text {; }\end{array}$}} \\
\hline & & & & \\
\hline \multicolumn{5}{|c|}{ Prob $>\operatorname{chi}^{2}=0.6977$} \\
\hline
\end{tabular}

The result in Table 3 shows the chi-square value of 3.84 with its probability value of 0.6977 which is greater than $5 \%$ significance level. The study does not reject null hypothesis of PMG estimator being preferred over the MG estimator. Deducing from the above results of the Hausman test, the study presents the estimates of PMG in examining the impact of trade openness on economic growth among ECOWAS member states. The Pooled Mean Group estimator constrains the longrun estimates from being the same across countries and allows only the short-run 
estimates of individual countries. This allows for heterogeneity without imposing cross-sectional restrictions in the short-run. Hence, the constrained long-run estimates and short-run estimates of ECOWAS member states are presented in Table 4 and Table 5 respectively.

Table 4: The Results of Pooled Mean Group Estimator (Long-Run Estimates)

\begin{tabular}{|c|c|c|c|c|c|c|}
\hline Variables & Coefficient & $\begin{array}{l}\text { Standard } \\
\text { Error }\end{array}$ & $\mathrm{z}$ & $\mathrm{P}>|\mathrm{z}|$ & \multicolumn{2}{|c|}{$\begin{array}{l}\text { [95\% Confidence } \\
\text { Interval] }\end{array}$} \\
\hline $\operatorname{lnITOP}$ & 0.20905 & 0.04712 & 4.44000 & $0.00000^{*}$ & 0.11670 & 0.30140 \\
\hline $\operatorname{lnLABF}$ & 0.64322 & 0.07375 & 8.72000 & $0.00000^{*}$ & 0.49867 & 0.78776 \\
\hline $\operatorname{lnGFCF}$ & -0.00534 & 0.00911 & -0.59000 & 0.55800 & -0.02319 & 0.01252 \\
\hline $\operatorname{lnFDI}$ & 0.02845 & 0.01946 & 1.46000 & 0.14400 & -0.00968 & 0.06659 \\
\hline lnGEX & 0.10798 & 0.02000 & 5.40000 & $0.00000^{*}$ & 0.06878 & 0.14718 \\
\hline $\operatorname{lnEXR}$ & 0.01965 & 0.00976 & 2.01000 & $0.04400^{*}$ & 0.00053 & 0.03877 \\
\hline
\end{tabular}

Note: The first figure in each cell is the estimated coefficient while the second is its probability value. This study uses $5 \%$ level of significance upon which the statistical significance of the estimated variables can be examined. The $\left({ }^{*}\right)$ denotes rejection of no statistical significance at $5 \%$ critical level. The PMG estimates in Table 4 shows that trade openness has positive and statistically significant influence on economic growth of ECOWAS member countries in the long-run at $1 \%$ level of observed significance. In the same vein, labour force and government expenditure have significant positive influence on growth of ECOWAS member countries at $1 \%$ level of observed significance while exchange rate is at $5 \%$ level of observed significance. This implies that increase in level of trade openness; labour force and government expenditure spur economic growth of ECOWAS member states. Gross domestic investment (Gross Fixed Capital Formation) has a negative impact on growth of ECOWAS countries but not highly significant at $5 \%$ level of observed significance while Foreign Investment (Foreign Direct Investment) has a positive impact on growth of ECOWAS countries but not significant at $5 \%$ level of observed significance. This implies that foreign and domestic investments do not influence growth in ECOWAS member countries. 
Benin: The PMG estimates show that trade openness is positive and statistically significant in influencing economic growth in the short-run at $5 \%$ level of observed significance. Apart from foreign trade openness, no other variable has significant influence on growth in Benin in the short-run at $5 \%$ level of observed significance.

Table 5: The Results of Pooled Mean Group Estimator (Short-Run Estimates)

\begin{tabular}{|c|c|c|c|c|c|c|c|c|c|}
\hline Country & $E C$ & $\mathrm{D}(\mathrm{RGDPP}(-1)$ & $\mathrm{D}(\ln \mid \mathrm{TOP})$ & $\mathrm{D}(\operatorname{InLABF})$ & $\mathrm{D}($ InGFCF $)$ & $\mathrm{D}(\operatorname{InFDI})$ & $\mathrm{D}(\ln \mathrm{InEX})$ & $\mathrm{D}(\operatorname{InEXR})$ & Constant \\
\hline \multirow[t]{2}{*}{ Benin } & -0.03040 & 0.01890 & 0.16080 & -0.21610 & 0.01880 & -0.08540 & 0.02480 & 0.00680 & -0.19000 \\
\hline & 0.27000 & 0.87400 & $0.000^{*}$ & 0.49900 & 0.20400 & 0.07500 & 0.27400 & 0.80000 & 0.28200 \\
\hline \multirow[t]{2}{*}{ Burkina-Faso } & -0.19980 & -0.21280 & -0.16590 & 1.19360 & 0.05180 & 0.02280 & 0.07220 & 0.03360 & -1.48200 \\
\hline & $0.00001^{*}$ & $0.00021^{*}$ & $0.00000^{*}$ & $0.00000^{*}$ & $0.00100^{*}$ & 0.61600 & $0.00100^{*}$ & 0.04500 & $0.00100^{*}$ \\
\hline \multirow[t]{2}{*}{ Cape Verde } & -0.00340 & 0.35210 & 0.05650 & 0.02790 & 0.20840 & -0.20060 & -0.30240 & 0.04200 & 0.03340 \\
\hline & 0.44800 & $0.00005^{*}$ & 0.31300 & 0.14300 & $0.01400^{*}$ & 0.29600 & $0.00100^{*}$ & 0.27700 & 0.16900 \\
\hline \multirow[t]{2}{*}{ Gambia } & -0.00140 & -0.22740 & 0.02980 & 0.38350 & 0.02060 & 0.03250 & 0.01620 & 0.01380 & -0.00400 \\
\hline & & 0.10100 & 0.31200 & 0.48400 & 0.14100 & 0.88600 & 0.22700 & 59800 & 0.97900 \\
\hline \multirow[t]{2}{*}{ Ghana } & -0.14380 & 0.00180 & 0.00240 & 0.97290 & 0.01670 & -0.00090 & 0.03370 & 0.00070 & -1.01350 \\
\hline & $0.00000^{*}$ & 0.98 & 0.87700 & $0.00000^{*}$ & 100 & 0.97400 & $0.04900^{*}$ & .89900 & $0.00000 *$ \\
\hline \multirow[t]{2}{*}{ Guinea } & -0.00450 & 0.44020 & 0.08200 & 0.05460 & 0.03940 & 0.02600 & 0.06640 & 0.01760 & -0.03770 \\
\hline & 0.87 & 0.00 & 0.0 & & & 600 & $0.00500^{*}$ & & 200 \\
\hline \multirow[t]{2}{*}{ Guinea-Bissau } & -0.01670 & -0.11020 & -0.06970 & -0.01850 & 0.17570 & 0.46580 & 0.00940 & 0.05510 & -0.10150 \\
\hline & 0.55600 & 0.41700 & 0.25300 & 0.87400 & $0.00200^{*}$ & 0.61500 & 0.79000 & 0.28800 & 0.52800 \\
\hline \multirow[t]{2}{*}{ Côte d'Ivoire } & -0.14480 & -0.00740 & -0.07300 & 1.58660 & 0.03900 & -0.00180 & -0.00110 & -0.02130 & -1.00860 \\
\hline & $0.00002^{*}$ & 0.96300 & 0.29900 & $0.00800^{*}$ & $0.02800^{*}$ & 0.96800 & 0.98100 & 0.57200 & $0.00300^{*}$ \\
\hline \multirow[t]{2}{*}{ Liberia } & -0.21580 & 0.28370 & 0.17560 & 0.13400 & 0.02090 & 0.05760 & -0.11060 & -0.06160 & -1.46150 \\
\hline & $0.00007^{*}$ & $0.03300^{*}$ & 0.06000 & 0.63800 & 0.85200 & 0.48800 & 0.25300 & 0.86300 & $0.01300^{*}$ \\
\hline \multirow[t]{2}{*}{ Mali } & -0.04420 & -0.34690 & -0.08150 & -0.55570 & 0.07340 & 0.01150 & 0.00310 & 0.01840 & -0.27110 \\
\hline & 0.27100 & $0.02000^{*}$ & 0.28900 & 0.27500 & 0.13800 & 0.86800 & 0.95100 & 0.78600 & 0.31300 \\
\hline \multirow[t]{2}{*}{ Niger } & -0.04400 & 0.12630 & -0.11530 & -0.08670 & 0.12080 & -0.10880 & -0.04910 & 0.01800 & -0.33840 \\
\hline & 0.09400 & 0.29100 & $0.03700^{*}$ & 0.62700 & $0.00000^{*}$ & 0.09500 & 0.26400 & 0.54500 & 0.08700 \\
\hline \multirow[t]{2}{*}{ Nigeria } & -0.18650 & -0.17800 & -0.03820 & 2.20200 & 0.01080 & -0.00660 & 0.06350 & -0.05110 & -1.46390 \\
\hline & $0.00003^{*}$ & 0.11000 & 0.13900 & $0.02500^{*}$ & 0.77000 & $0.00000^{*}$ & $0.00100^{*}$ & $0.023^{*}$ & $0.00300^{*}$ \\
\hline \multirow[t]{2}{*}{ Senegal } & -0.01040 & -0.27800 & -0.03210 & 0.04740 & 0.07310 & 0.06800 & -0.05970 & -0.04970 & 0.07460 \\
\hline & 0.11900 & $0.02700^{*}$ & 0.44100 & $0.02500^{*}$ & $0.01300^{*}$ & 0.26000 & 0.09400 & 0.06700 & 0.10200 \\
\hline \multirow[t]{2}{*}{ Sierra-Leone } & -0.50280 & -0.52440 & -0.02870 & -0.66070 & 0.00110 & -0.05410 & 0.02130 & 0.13640 & -3.46030 \\
\hline & $0.00000^{*}$ & $0.00000^{*}$ & 0.58300 & 0.06500 & 0.72200 & 0.46300 & 0.53500 & $0.003^{*}$ & $0.00000^{*}$ \\
\hline \multirow[t]{2}{*}{ Togo } & -0.07170 & -0.07460 & 0.09870 & -0.26650 & 0.07990 & 0.02110 & -0.02740 & 0.05730 & -0.48730 \\
\hline & 0.06900 & 0.60300 & 0.14100 & 0.44800 & $0.00004 *$ & 0.66200 & 0.58500 & 0.43700 & 0.06800 \\
\hline
\end{tabular}

Note: The first figure in each cell is the estimated coefficient while the second is its probability value. This study uses $5 \%$ level of significance upon which the statistical significance of the estimated variables can be examined. The $\left(^{*}\right)$ denotes rejection of no statistical significance at $5 \%$ critical level. This implies that trade openness spurs growth in the country as it has progressively liberalized its economy and has geographical advantage which is reflected in the strong demand for Beninese cotton on world markets while the port of Cotonou has remained a transit corridor for hinterland countries such as Burkina Faso, Mali, and Niger 
(African Economic Outlook-AEO, 2019).

Burkina-Faso: Trade Openness impacted negatively and significantly on growth in the short-run at $5 \%$ level of observed significance. This is because the country is land-locked and vulnerable to rainfall shocks and price fluctuations in export commodities fluctuations (AEO, 2019). According to AEO (2019), trade in Burkina-Faso with regional partners remains weak due partly to non-tariff barriers. The findings also show that the lagged dependent variable, trade openness, labour force, gross fixed capital formation and government expenditure have significant negative influence on growth in Burkina-Faso at $5 \%$ level of observed significance. The speed of adjustment is negative $(-0.1998)$ and significant. This implies that trade openness is prone to short-run external shocks and that trade comprises more of imports than exports. However, there are prospects of positive growth in the long-run.

Cape Verde: The impact of foreign trade openness is not significant on growth in Cape Verde in short-run at $5 \%$ level of significance. This can be attributed to the fact that Cape Verde has been increasingly dependent upon imports, especially for foodstuff and manufactured goods which have led to severe trade imbalance. In addition, the export of narrow range of products mostly raw materials that have less value addition and subject to price fluctuations at international markets have affected the county's trade balance (AEO, 2019). Other variables that significantly influence economic growth positively are: previous RGDPP and gross fixed capital formation while government expenditure has a negative influence on growth in the short-run.

Gambia: Estimated coefficient shows positive impact of foreign trade openness on economic growth in the short-run. The impact however, is not significant at $5 \%$ level of observed significance. This may be attributed to the fact that Gambia is a land-locked country and has an average unfavourable trade balance of US\$ 73.268 million (-10.18\%) (World Bank, 2019). All other estimates show a negative influence on growth in the short-run but not significant at $5 \%$ level. 
Ghana: Foreign trade openness shows positive influence on growth in the Ghanaian economy in short-run. However, the impact is not significant at $5 \%$ level of observed significance. This means that trade has not contributed significantly to growth in the Ghanaian economy in the short-run due to a trade balance that averaged US\$ 1.601 billion (-9.77\%) over period of study (World Bank, 2019). More so, dependence on primary commodity exports continues to expose the economy to shocks in international commodity prices which could weaken economic growth and the current account balance (African Economic Outlook-AEO, 2019). Only labour force and government expenditure significantly influenced economic growth positively in the short-run. The speed of adjustment is $-14.38 \%$ suggesting that the model has significant ability to revert back to long-run equilibrium by $14.38 \%$ yearly.

Guinea: Trade Openness impacts positively and significantly on growth in Guinea in the short-run at $5 \%$ level of observed significance. This is because the country is driven by increased production of bauxite and gold as well as a resilient agricultural and industrial sector (AEO, 2019). Apart from previous RGDPP and government expenditure that shows significant positive influence on growth in Guinea, all other variables captured in the model have no significant influence on growth in Guinea.

Guinea-Bissau: Trade openness in Guinea-Bissau is negative and insignificant to growth in the short-run at $5 \%$ level of observed significance. This means that increased level of trade openness was not accompanied by corresponding volume of favourable trade. This is because the economy is fragile and highly dependents on the social and political climate and the performance of agriculture especially the rice and cashew nut sub-sector (AEO, 2019). Only gross fixed capital formation has positive and significant impact on economic growth in the country.

Cote D'Ivoire: Result shows negative influence of foreign trade openness on growth in Cote D'Ivoire. The influence is not significant in the short-run at 5\% level of observed significance. This may be connected to the effects of the civil war in 2002 and the unfavourable reduction in the country's exports and increase in imports and the reduction in import tariff rates. Only gross fixed capital for- 
mation and labour force have significant positive influence on economic growth in Cote D'Ivoire in the short-run. The speed of adjustment to long-run equilibrium is $14.48 \%$ yearly.

Liberia: Trade openness has a positive but not significant relationship with growth in the short-run at $5 \%$ level of observed significance. This is because the Liberian economy is more open and has witnessed unfavourable trade throughout the study period with relatively low tariffs on imported goods. In addition, Liberia's trade openness showed steady and stable growth throughout the study period due to the favourable climate for agriculture and increase in the level of iron ore and rubber. Only previous real GDP per capita has highly significant positive influence on growth in Liberia. The speed of adjustment is significant implying that growth in Liberia converges at $21.58 \%$ yearly.

Mali: Trade openness is negative but not significant. This means foreign trade openness in the country has not contributed to economic growth in Mali. This may be attributed to the widespread bureaucratic inefficiency that hinders dynamic private sector growth and non-tariff measures in the country (The Heritage Foundation, 2019). The current account deficit has risen from $6.0 \%$ in 2017 to $6.5 \%$ in 2018 (AEO, 2019). Only previous RGDPP has significant negative influence on growth in Mali.

Niger: Trade openness in Niger has a negative and significant impact on economic growth in the country in the short-run at $5 \%$ level of observed significance. The negative impact of trade openness may be connected to the fact that the economy is basically subsistence in nature and it specializes in the exportation of food stuff and raw minerals to world markets (AEO, 2019; ITC, 2017). Gross Fixed Capital Formation has a positive influence on growth of the country in the short-run.

Nigeria: Trade openness has no significance influence on growth in the Nigerian economy in the short-run at $5 \%$ significance level. This may be attributed to the fact that crude oil dominated Nigeria's exports of which price and quantity sold is determined on the international market (Olufemi, 2004). Besides, imports are 
skewed towards semi-finished or finished goods which hinder the development of local industries. However, labour force, foreign direct investment and government spending have positive influence on the growth of the Nigerian economy in the short-run. The result also shows that exchange rate has a negative influence on the growth of the Nigerian economy in the short-run. This implies that exchange rate appreciation adversely affects growth of the Nigerian economy. This may be due to the nature of Nigeria's trade where the country exports raw materials and imports consumables or finished goods which puts pressure on the exchange rate. It was found that the speed at which distortions may be corrected in the long-run is at $18.65 \%$ yearly in case of any initial disequilibrium.

Senegal: Trade openness has negative influence on growth in Senegal but it is not significant at $5 \%$ level of observed significance. This is because the economy is vulnerable to deteriorating competitiveness due to her limited flexibility to adjust to external shocks (AEO, 2019). However, labour force and gross fixed capital formation have significant positive influence on growth in the short-run while previous real GDP per capita has strong negative influence on current economic growth in the country.

Sierra-Leone: Trade openness shows a negative but not significant influence on growth in Sierra-Leone in the short-run at $5 \%$ level of observed significance. This is due to increased imports of consumer goods and weak export performance by the country as most of the country's exports are unprocessed such as: diamonds, gold, cashew nuts and iron ore while much of the imports include rice, petroleum and machinery (AEO, 2019). Previous real RGDP has a strong negative influence on economic growth in the short-run while exchange rate has significant positive influence on economic growth in the country. The study finds that initials distortions may be corrected speedily at $50.28 \%$ yearly to long-run equilibrium.

Togo: The result shows a positive but not significant influence of foreign trade openness on growth in the short-run at $5 \%$ level of observed significance. The result also shows that gross fixed capital formation has strong positive influence on growth in the Togolese economy in the short-run. 


\subsection{Discussion of Results}

Analysis of the 15 ECOWAS member countries concerning the impact of trade openness on economic growth shows that trade openness has highly significant positive influence on growth of ECOWAS member countries in the long-run. In the Short-run, trade openness has strong positive influence on growth in Benin and Guinea and a significant negative influence on growth in Burkina-Faso and Niger. This implies that trade is beneficial to ECOWAS member countries in the long-run unlike the short-run where the impact of trade openness differ across countries. It can therefore be inferred from above that trade openness has a strong positive influence on economic growth among ECOWAS member countries in the long run than in the short run. However, in the short-run, countries like Sierra-Leone, Senegal, Burkina-Faso and Cote D'Ivoire that export primary products such as cocoa, fish, ores, peanuts, palm kernels, etc. experience weak growth as these commodities do not command high prices on international markets.

The study concludes that foreign trade openness significantly influences growth of most ECOWAS member countries in the long-run and that international trade is more beneficial to countries that have improved quality of exports where the value is relatively higher than imports. For example; export of chemicals, gold and petroleum gas in Niger and gold, diamonds and coffee in Guinea.

\subsection{Conclusion and Policy Recommendations}

\subsection{Conclusion}

The study concludes that trade openness is important for economic growth among ECOWAS member states in the long run. However, the volume and value of trade as a percent of GDP affects the growth of some ECOWAS member countries in the short run negatively. These countries include: Burkina-Faso, Guinea-Bissau, Cote D'Ivoire, Mali, Niger, Nigeria, Senegal and Sierra-Leone.

\subsection{Policy Recommendations}

The study therefore recommends that ECOWAS member countries improve co- 
operation among economic actors by using export consortia to help SMEs in the region access the international markets. In addition, they should combine shortterm and long term export-led-growth policies such as export promotion policies and other domestic policies aimed at enhancing productivity and technological content of domestic products. More so, the countries should pursue a twin strategy of trade and competitiveness. This is because, improved exports is fundamental for countries' economic competitiveness which in turn boosts growth. In addition, there should be infrastructure development to further enhance private enterprise investments that are more productive and boost incomes.

\section{References}

Abramovitz, M. (1986). Catching up, forging ahead, and falling behind. Journal of Economic History, 46(2), 385-406.

African Economic Outlook-AEO (2019). Macroeconomic performance and prospects, Jobs, growth, and firm dynamism Integration for Africa's economic prosperity. African Development Bank. Retrieved from https://www.afdb.org/fileadmin/uploads/afdb/Documents/Publications/ 2019AEO/AEO_2019-EN.pdf

Barro, R.J. \& X. Sala-i-Martin (2004). Economic growth (2nd ed.), Cambridge: MIT Press.

Blundell, R., Bond, S., \& Windmeijer, F. (2009). Estimation in dynamic panel data models: improving on the performance of the standard GMM estimator. Non-stationary Panels, Panel Cointegration and Dynamic Panels. 15, 53-91.

Cara, K. (2015). What is trade openness and what is the effect of trade openness on economic financial development?

Retrieved from https://www.enotes.com/homework-help/what-trade-openness87695

Chang, R., Kaltani, L., \& Loayza, N. V. (2009). Openness can be good for growth: The role of policy complementarities. Journal of Development Economics, 90(1), 33-49.

Eicher, T. (1999). Trade, development and converging growth rates: dynamic gains from trade reconsidered. Journal of International Economics, 48(1), $179-198$.

Gerschenkron, A. (1962). Economic Backwardness in Historical Perspective. Cambridge: Harvard. 
Grossman, G., \& Helpman, E. (1991). Innovation and Growth in the Global Economy, Cambridge: The MIT Press.

Hadri, K. (2000). Testing for stationarity in heterogeneous panel data. Econometric Journal, 3, 148-161.

Igudia, P. (2004). Globalization and economic development: Nigeria's experience and prospects, globalization and Africa's economic development, Ibadan: Nigerian Economic Society, 347-375.

Im, K. S., Pesaran, M. H., \& Shin, Y. (2003). Testing for unit roots in heterogeneous panels. Journal of Econometrics, 115, 53-74.

International Trade Centre-ITC (2017). Evolution of Trade in West African Countries.

Retrieved from http://www.intracen.org/

Iyoha, M., \& Okim, A. (2017). The impact of trade on economic growth in ECOWAS member countries: evidence from panel data. CBN Journal of Applied Statistics, 8(1), $23-49$.

Kim, D. H., Lin, S. H., \& Suen, Y. B. (2016). Trade, growth and growth volatility: new panel evidence. International Review of Economics and Finance, 45, 384-399.

Lee, J. (1993). International trade, distortions, and long-run economic growth. International Monetary Fund Staff Papers, 40(2), 299-328.

Levin, A., Lin, C. F., \& Chu, C. (2002). Unit root tests in panel data: asymptotic and finite-sample properties. Journal of Econometrics, 108, 1-24.

Lucas, R. E. (1988). On the mechanic of economic development. Journal Monetary Economics. 46 (1), 167-182.

Mankiw, N., Romer, D., \& Weil, D. (1992). A Contribution to the empirics of economic growth. Quarterly Journal of Economics, 107(2), 407-437.

Manwa, F., \& Wijeweera, A. (2016). Trade liberalization and economic growth link: The case of Southern African custom union countries. Economic Analysis and Policy. (16), 1-28.

Matsuyama, K. (1992). Agricultural productivity, comparative advantages, and economic growth. Journal of Economic Theory, 58, 317-334.

Olufemi, S. M. (2004). Trade Openness and Economic Growth in Nigeria: Further Evidence on the Causality Issue. South African Journal of Economic and Management, 7(2), 299-315 
Oluwatoyin, M. A., \& Folasade, A. B. (2014). Trade openness, institutions and economic growth in sub-Saharan Africa (SSA). Developing Country Studies, $4(8), 1-14$.

Organisation for Economic Co-operation and Development-OECD (2001). The Well-being of Nations: The Role of Human and Social Capital, OECD Publishing, Paris.

Redding, S. (1999). Dynamic comparative advantage and the welfare effects of trade. Oxford Economics Papers, 51(1), 15-39.

Solow, R. M. (1956). A contribution to the theory of economic growth. Quarterly Journal of Economics Oxford Journals, 70(1), 65-94.

Swan, T. W. (1956). Economic growth and capital accumulation. Economic Record. Wiley, 32(2), 334-361.

The Heritage Foundation (2019). Mali: 2019 Index of Economic Freedom. Retrieved from https://www.heritage.org/index/country/mali.

Veblen, T. (1915). Imperial Germany and the Industrial Revolution. London: Macmillan.

World Bank (2019). World Development Indicators. Retrieved from https://data.worldbank.org/country

Young, A. (1991). Learning by doing and the dynamic effects of international trade. Quarterly Journal of Economics, 106(1), 369 - 405.

Zahonogo, P. (2017). Trade and economic growth in developing countries: 3 evidence from Sub-Saharan Africa. Journal of African Trade.

* Note: Supplementary information about this research is available on request from the author. 